Available online at GSC Online Press Directory

GSC Biological and Pharmaceutical Sciences

e-ISSN: 2581-3250, CODEN (USA): GBPSC2

Journal homepage: https://www.gsconlinepress.com/journals/gscbps

(RESEARCH ARTICLE)

\title{
Chemical compositions and antioxidant activity of leaf and stem essential oils of Bryophyllum pinnatum (lam.) Kurz
}

\author{
Mbachu Kingsley Adibe ${ }^{1,}{ }^{*}$, Ibok Michael Gabriel ${ }^{1}$, Adeniyi-Akee Mukaram Akintunde 2 and Ajala Omotola \\ Esther 1
}

${ }^{1}$ Department of Chemistry, University of Ibadan, Ibadan, Nigeria.

${ }^{2}$ Department of Pharmaceutical Chemistry, College of Pharmacy, Igbinedion University, Nigeria.

Publication history: Received on 27 September 2019; revised on 30 October 2019; accepted on 01 November 2019

Article DOI: https://doi.org/10.30574/gscbps.2019.9.2.0184

\begin{abstract}
Essential oils of air-dried samples of leaf and stem Bryophyllum pinnatum obtained by hydro-distillation in an all glass clevenger-type apparatus gave percentage yield of 0.14 and 0.55 respectively. The essential oils (EOs) were subjected to analysis using gas chromatography (GC), gas chromatography-mass spectrometry (GC-MS). Fifteen (15) compounds representing $97.78 \%$ of $B$. pinnatum leaf essential oil and seventeen (17) compounds, accounting for $97.23 \% B$. pinnatum stem essential oil were identified. The major compounds present in leaf $B$. pinnatum essential oil were 1octen-3-ol (19.52\%), supraene (16.63\%), 1-heneicosanol (12.00\%), 2,5-dimethylheptane (8.42\%) and (E)-9-eicosene $(6.90 \%)$ while the main compounds of B. pinnatum stem were (E)-5-eicosene (25.71\%), oleamide (20.25\%), isolongifolol (13.07\%) and $\beta$-gurjunene (7.71\%). Both leaf and stem essential oils contain oleamide $(5.63 \%$ and $20.25 \%)$, (E)-5-eicosene (6.99\% and $25.71 \%)$, hexahydropseudoionone $(2.24 \%$ and $2.66 \%)$ and phytol $(3.73 \%$ and $3.09 \%$ ) respectively. The Inhibitory concentration ( $\mathrm{IC}_{50}$ ) values (in $\mu \mathrm{g} / \mathrm{mL}$ ) of scavenging activity of the leaf essential oil were 789 and stem essential oil had 829 compared to standards (butylated hydroxyl anisole 40.39 and ascorbic acid 55.22) which indicated a moderate antioxidant activity. We report the chemical compound present in leaf and stem essential oils and their antioxidant properties.
\end{abstract}

Keywords: Bryophyllum pinnatum; Antioxidant; Essential oil; Hydro-distillation; Gas Chromatography-Mass spectrometry

\section{Introduction}

Bryophyllum pinnatum (Lam.) Kurz., (Crassulaceae) commonly known as the leaf of Life or life plant is a succulent perennial medicinal herb that grows 3 - 5 feet tall, with a fleshy dark green foliage, distinctively scalloped and hemmed in red and pendulous flowers [1]. It usually grows in tropical, sub-tropical and warm temperate climatic zone used in folk medicine in Africa, tropical America, India, China and Australia. The plant is available throughout the Southern part of Nigeria [2]. Some species are cultivated as ornamentals [3][4]. B. pinnatum is known as a universal antidote due to its abundant medicinal uses for the treatment of several ailments and it is well known for haemostatic and wound healing properties [3]. The leaf and bark are bitter tonic, astringent to the bowels, analgesic; useful in diarrhoea and vomiting [5]. It is used either externally or internally for all types of pains and inflammations, various bacterial, viral and fungal infections, leishmaniasis, upper respiratory infections, stomach ulcers, flu and fever [6]. The pharmacological activities on different extracts and fractions showed significant neuropharmacological effect [7], antinociceptive, antiinflammatory, antidiabetic [8][9][10], antimicrobial [11][12][13], anti-ulcer[14] and antitumor activities [15]. Several active compounds have been isolated from this specie. They include: Syringic acid, caffeic acid, 4-hydroxy-3-methoxycinnamic acid, 4-hydroxybenzoic acid, p-hydroxycinnamic acid, p-coumaric acid, ferulic acid, phosphoenol pyruvate,

\footnotetext{
* Corresponding author

E-mail address: mbakings4u@yahoo.com
} 
protocatechuic acid from aerial parts of the plant [16]. Its leaf contains astragalin, 3,8-dimethoxy-4,5,7trihydroxyflavone, friedelin, epigallocatechin-3-o-syringate, luteolin, kaempferol [17], the plant is a good source of bufadienolides [18]. The cardienolide and steroidal contents includes $\beta$-sitosterol, bryophyllol, bryophynol, bryophyllin A \& B, bryotoxin C, bufadienolide-1,3,5-orthoacetate with potent cytotoxicity [19][20][21][15][22][23]. Essential oils obtained from plant samples have been reported to possess unique medicinal effects such as digestive, antimicrobial, antioxidant, cytotoxic, antifungal, hypoglycemic and antispasmodic activities [24][25][26][27]. The essential oil composition of leaf Bryophyllum pinnatum had been evaluated [28], but no account of biological and antioxidant activities were conducted. As a result of the medicinal importance of $B$. pinnatum, therefore, this research is aimed to determine the chemical constituents of the leaf and stem essential oils of $B$. pinnatum and the antioxidant activity using 1,1-diphenyl-2-picrylhydrazyl radical (DPPH).

\section{Material and methods}

\subsection{Plant materials}

Bryophyllum pinnatum leaf and stem were collected from Forestry Research Institute of Nigeria (FRIN), Ibadan, identified and authenticated at the herbarium unit, Department of Botany, University of Ibadan, Nigeria where voucher samples had been deposited, with voucher number UIH-22780.

\subsection{Extraction of essential oils}

Sample of Bryophyllum pinnatum was collected, which were separated into leaf and stem parts giving $834 \mathrm{~g}$ and $211 \mathrm{~g}$ respectively. They were crushed separately and hydro-distilled for 3 hours in an all glass Clevenger-type apparatus designed to British Pharmacopeia specifications [29]. Oils were collected under an iced condition with $1 \mathrm{~mL}$ of distilled n-hexane, which the analysing GC corrected. The essential oils were obtained and stored at $4{ }^{\circ} \mathrm{C}$ before analysis [30].

\subsection{Identification and quantification of the essential oil constituents}

Leaf and stem Bryophyllum pinnatum essential oils were subjected to GC-MS analysis on an Agilent 7809 A Gas Chromatography hyphenated with an Agilent Mass Detector having split/splitless injector interfaced to mass selective detector operating at $70 \mathrm{eV}$. The ion source temperature was set to $200{ }^{\circ} \mathrm{C}$ over a mass spectral range of m/z $50-700$ at a scan rate of $1428 \mathrm{amu} / \mathrm{sec}$. The column of the GC used was HP-5MS with a length of $30 \mathrm{~m}$, with an internal diameter of $0.25 \mathrm{~mm}$ and a film thickness of $0.25 \mu \mathrm{m}$. The oven temperature was programmed as follows: initial temperature 80 ${ }^{\circ} \mathrm{C}$ for $2 \mathrm{~min}$, increased at $10{ }^{\circ} \mathrm{C} / \mathrm{min}$ to a temperature of $240{ }^{\circ} \mathrm{C}$ for 6 minutes. Helium was used as the carrier gas at a flow rate of $1 \mathrm{~mL} / \mathrm{min}$. Injection volume, linear velocity and pressure were adjusted at $1.0 \mu \mathrm{L}, 362 \mathrm{~cm} / \mathrm{s}$ and $56.2 \mathrm{KPa}$ respectively. The oven temperature was set at $60{ }^{\circ} \mathrm{C}$, hold for $1 \mathrm{~min}$ to $180{ }^{\circ} \mathrm{C}$ for $3 \mathrm{~min}$ at $10{ }^{\circ} \mathrm{C} / \mathrm{min}$, the final temperature was $280{ }^{\circ} \mathrm{C}$ for $2 \mathrm{~min}$ at $10{ }^{\circ} \mathrm{C} / \mathrm{min}$ both the injector and detector temperatures were fixed at $250{ }^{\circ} \mathrm{C}$. Identification of the essential oil components were based on comparison of mass spectral fragmentation patterns (NIST database 14.L/chemstation data system) with the data previously reported in the literature [31][32].

\subsection{Antioxidant inhibition assay}

The effects of 1,1-diphenyl-2-picrylhydrazyl (DPPH) free radical scavenging assay of the essential oils were determined according to Onocha et al [33]. DPPH (3.95 mg) was dissolved in methanol (100 mL) to give $100 \mu \mathrm{M}$ of methanolic DPPH. Aliquots of $0.5 \mathrm{~mL}$ of methanol solutions of each, containing essential oils in triplicates were added to $2.0 \mathrm{~mL}$ of methanolic DPPH. The absorbance at $517 \mathrm{~nm}$ was noted after 10 minutes in UV-Spectrophotometer. Five serially diluted concentrations $(1000 \mu \mathrm{g} / \mathrm{mL}, 500 \mu \mathrm{g} / \mathrm{mL}, 250 \mu \mathrm{g} / \mathrm{mL}, 125 \mu \mathrm{g} / \mathrm{mL}$ and $62.5 \mu \mathrm{g} / \mathrm{mL})$ of the essential oil samples were prepared. The same procedure was carried out on butylated hydroxyl anisole (BHA) and ascorbic acid, which are standard antioxidants. The decrease in absorption was measured against that of the control (methanolic DPPH without samples) and the percentage inhibition was also calculated using the formula:

$$
\% \mathrm{I}=\frac{\mathrm{Ac}-\mathrm{As}}{\mathrm{Ac}} \times 100
$$

Where Ac is absorbance of the control, As is absorbance of sample and \% I is percentage inhibition. All tests and analyses were done in triplicates and the average was obtained. The scavenging activity was expressed in terms of $50 \%$ Inhibition concentration ( $\mathrm{IC}_{50}$ ), the concentration of the samples required to give a $50 \%$ reduction in the intensity of the signal of the DPPH radical, was evaluated from the graph representing the percentage inhibition against sample concentration using regression analysis on Microsoft Excel. 


\section{Results and discussion}

Essential oils from leaf and stem Bryophyllum pinnatum obtained by hydro-distillation gave colourless herbal aroma. The percentage yields obtained were 0.14 and 0.55 for B. pinnatum leaf and B. pinnatum stem respectively [Table 1]. The oils were analysed using Gas Chromatography [GC], Gas Chromatography-Mass Spectrometry [GC-MS]. The chromatograms were presented in Figs 1 and 2. Fifteen (15) compounds representing 97.23\% of leaf essential oil of $B$. pinnatum and Seventeen (17) compounds making a total of $97.98 \%$ of Stem essential oil of B. pinnatum were identified. Results of the 28 identified compounds in both leaf and stem essential oil and comparison of the amount of classes of compounds found in the two essential oils were presented in Table 2. The percentage Inhibition (\% I) and inhibitory concentration $\left(\mathrm{IC}_{50}\right.$ ) of leaf and stem B. pinnatum essential oils compared with reference standard were shown in Table 3. Structures of some terpene/terpenoid from leaf and stem essential oil of $B$. pinnatum were presented in Fig 3 while percentage inhibition of leaf and stem oils at different concentration compared with standards were made known in Fig 4.

Table 1 Essential oils obtained from leaf and stem parts of Bryophyllum pinnatum

\begin{tabular}{llllll}
\hline Plant parts & Weight of sample (g) & $\begin{array}{l}\text { Weight of essential oil } \\
\text { obtained (g) }\end{array}$ & $\begin{array}{l}\text { \% Yield of } \\
\text { essential oil } \\
\text { obtained }\end{array}$ & $\begin{array}{l}\text { Odour } \\
\text { assessment }\end{array}$ \\
\hline Leaf & 834 & 1.17 & 0.14 & Leafy aroma \\
Stem & 211 & 1.16 & 0.55 & Herbal aroma \\
\hline
\end{tabular}

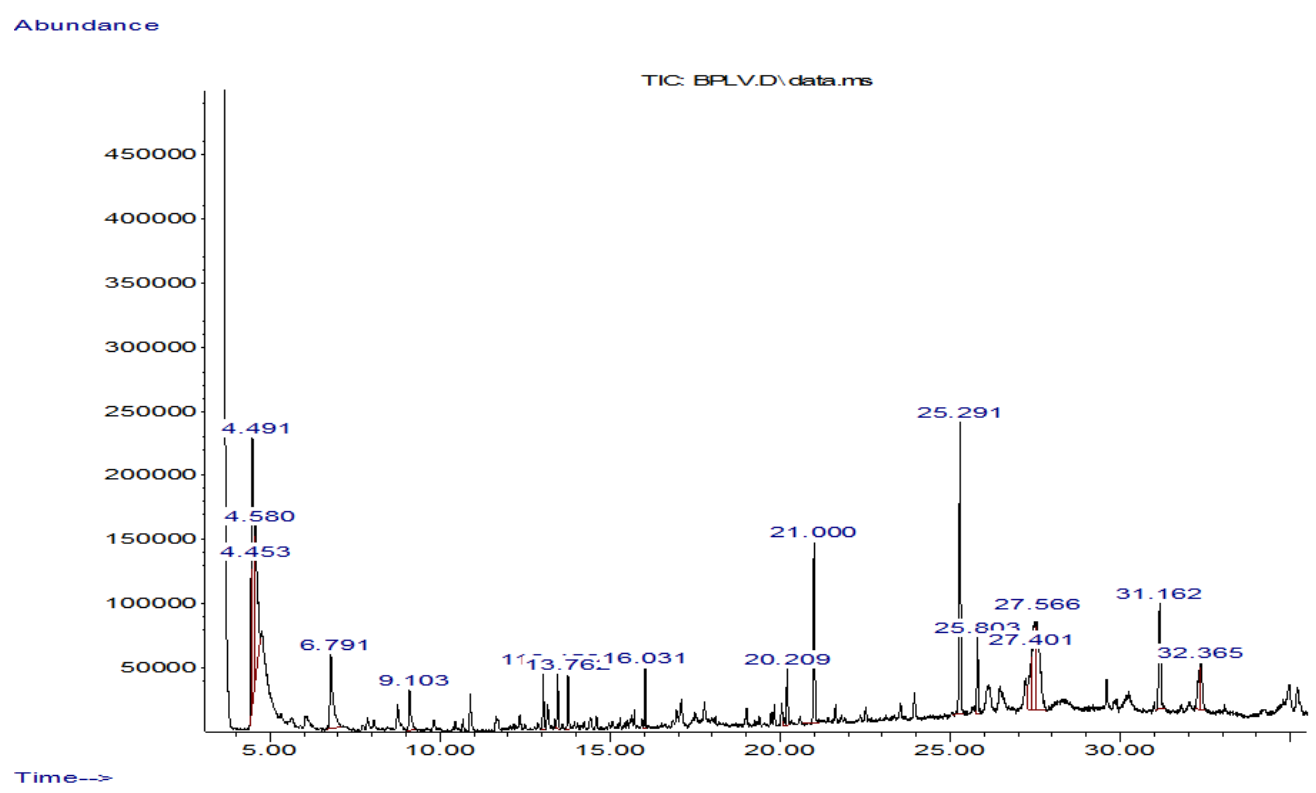

Figure 1 Gas chromatogram of the leaf essential oil of Bryophyllum pinnatum

The significant compounds present in B. pinnatum leaf essential oils include, 1-octen-3-ol (19.52\%), supraene (16.63\%), 1-heneicosanol (12.00\%), 2,5-dimethylheptane (8.42\%), (E)-5-eicosene (6.90\%), oleamide (5.63\%), tritetracontane (5.09\%), phytol (3.09\%), trans-fernesol (3.96\%) and $\beta$-cyclocitral $(2.32 \%)$ while the remaining compounds appeared in trace amount. 


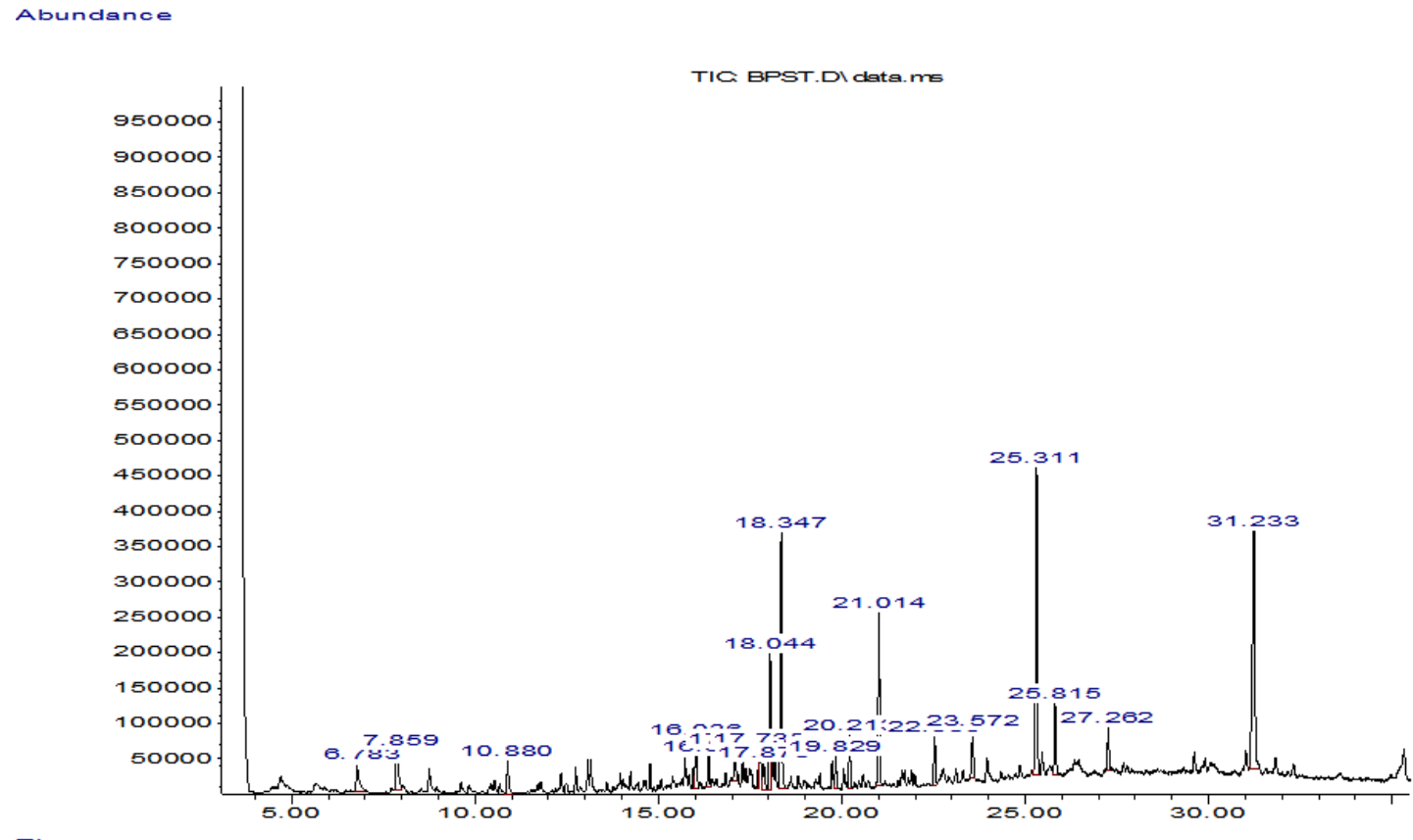

Figure 2 Gas chromatogram of the stem essential oil of Bryophyllum pinnatum

The most abundant compounds present in stem essential oil were (E)-5-eicosene (25.71\%), oleamide (20.25\%), 5isolongifolol (13.07\%) and $\beta$-gurjunene (7.71\%). The stem oil also features significant quantities of (E)-2-nonenal (3.30\%), phytol (3.73\%), $\beta$-bisabolene $(2.95 \%)$, hexahydropseudoionone $(2.66 \%)$, cycloheptane $(2.60 \%)$ and $(\mathrm{Z})$ hexadecanamide (2.09\%) [Table 2]. However, both leaf and stem essential oils contain oleamide (5.63\% and 20.25\%), (E)-5-eicosene (6.99\% and $25.71 \%)$, hexahydropseudoionone $(2.24 \%$ and $2.66 \%)$ and phytol $(3.73 \%$ and $3.09 \%)$ respectively. The leaf oil consists of $32.90 \%$ terpene/terpenoid while total terpene/terpenoid present in stem essential oil was $59.42 \%$. The essential oils had a significant amount of sesquiterpenes/sesquiterpenoids such as $\beta$-gurjunene, isolongifolol etc and diterpenes which include phytol. This result when compared with an earlier report by Aboaba et al [28] showed variation in identified compounds, which could be as a result of differences in plant location. Their report had given a basis for comparison, and we have improved on it.

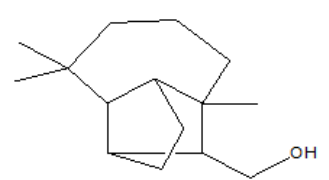

Isolongifolol<smiles>C=C(CCC=C(C)C)C1CC=C(C)CC1</smiles>

B-Bisabolene<smiles>CC(=CCO)CCCC(C)CCCC(C)CCCC(C)C</smiles>

Phytol<smiles>CC1CCC=C2CCC3C(C3(C)C)C21C</smiles>

B-Gurjunene<smiles>CC(=CCO)CCCC(C)C</smiles>

Citronellol

Figure 3 Structures of some terpene/terpenoid from leaf and stem essential oil of B. pinnatum

The results for antioxidant activity and scavenging ability on DPPH radicals of the two essential oils [Table 3 and Figure 3] revealed moderate activity of the oils compared to the standards as shown by the percentage inhibition (\% I) and inhibitory concentration $\left(\mathrm{IC}_{50}\right)$ of the result obtained. The effectiveness of the essential oils and the reference standards were in descending order, thus; BHA > Ascorbic acid > Bpleaf $>$ Bpstem. The ethno-medicinal activity of the two essential oils may be dependent on the compounds present in these oils. 
Table 2 Chemical compositions of leaf and stem essential oils of Bryophyllum pinnatum

\begin{tabular}{|c|c|c|c|c|c|c|}
\hline \multirow[t]{2}{*}{$\mathbf{S} / \mathbf{N}$} & \multirow{2}{*}{$\begin{array}{l}\text { Retention } \\
\text { time (min) }\end{array}$} & \multirow[t]{2}{*}{ Compounds } & \multirow{2}{*}{$\begin{array}{l}\text { Molecular } \\
\text { formula }\end{array}$} & \multirow{2}{*}{$\begin{array}{l}\text { Molecular weight } \\
\text { (g/mol) }\end{array}$} & \multicolumn{2}{|c|}{$\%$ Area } \\
\hline & & & & & leaf & Stem \\
\hline 1 & 4.45 & 1-octen-3-ol & $\mathrm{C}_{8} \mathrm{H}_{16} \mathrm{O}$ & 128.22 & 19.52 & - \\
\hline 2 & 4.58 & 2,5-dimethylheptane & $\mathrm{C}_{9} \mathrm{H}_{20}$ & 128.26 & 8.42 & - \\
\hline 3 & 6.78 & cycloheptane & $\mathrm{C}_{7} \mathrm{H}_{14}$ & 98.19 & - & 2.60 \\
\hline 4 & 6.79 & nonanal & $\mathrm{C}_{9} \mathrm{H}_{18} \mathrm{O}$ & 142.24 & 6.18 & - \\
\hline 5 & 7.86 & (E)-2-nonenal & $\mathrm{C}_{9} \mathrm{H}_{16} \mathrm{O}$ & 140.23 & - & 3.30 \\
\hline 6 & 9.10 & $\beta$-cyclocitral & $\mathrm{C}_{10} \mathrm{H}_{16} \mathrm{O}$ & 152.23 & 2.32 & - \\
\hline 7 & 10.88 & (E,E) 2,4-decadienol & $\mathrm{C}_{10} \mathrm{H}_{16} \mathrm{O}$ & 152.23 & - & 1.95 \\
\hline 8 & 13.46 & $\begin{array}{l}\text { 2-ethenyl-1,3,3-trimethyl- } \\
\text { cyclohexene }\end{array}$ & $\mathrm{C}_{11} \mathrm{H}_{18}$ & 150.26 & 2.01 & - \\
\hline 9 & 13.76 & trans- $\beta$-ionone & $\mathrm{C}_{13} \mathrm{H}_{20} \mathrm{O}$ & 192.3 & 1.84 & - \\
\hline 10 & 16.03 & $\begin{array}{l}\text { 1,1-(1,2-dimethyl-1,2- } \\
\text { ethanediyl)-bis-cyclohexane }\end{array}$ & $\mathrm{C}_{13} \mathrm{H}_{30}$ & 222.41 & 1.86 & - \\
\hline 11 & 16.04 & $\beta$-Bisabolene & $\mathrm{C}_{15} \mathrm{H}_{24}$ & 204.35 & - & 2.95 \\
\hline 12 & 16.37 & $\begin{array}{l}\text { 2,7-dimethyl-3,6- } \\
\text { bis(methylene)-1,7-Octadiene }\end{array}$ & $\mathrm{C}_{12} \mathrm{H}_{18}$ & 162.27 & - & 1.62 \\
\hline 13 & 17.08 & 1-Tetradecanol & $\mathrm{C}_{14} \mathrm{H}_{30} \mathrm{O}$ & 214.39 & - & 2.10 \\
\hline 14 & 17.74 & 8,9-dehydrocycloisolongifolene & $\mathrm{C}_{15} \mathrm{H}_{22}$ & 202.34 & - & 1.68 \\
\hline 15 & 17.87 & Benzenepropanamine & $\mathrm{C}_{10} \mathrm{H}_{15} \mathrm{~N}$ & 149.23 & - & 1.64 \\
\hline 16 & 18.04 & $\beta$-Gurjunene & $\mathrm{C}_{15} \mathrm{H}_{24}$ & 204.35 & - & 7.71 \\
\hline 17 & 18.35 & Isolongifolol & $\mathrm{C}_{15} \mathrm{H}_{26} \mathrm{O}$ & 222.37 & - & 13.07 \\
\hline 18 & 19.83 & Isopropyl myristate & $\mathrm{C}_{17} \mathrm{H}_{34} \mathrm{O}$ & 270.45 & - & 1.55 \\
\hline 19 & 20.21 & Hexahydropseudoionone & $\mathrm{C}_{13} \mathrm{H}_{26} \mathrm{O}$ & 198.34 & 2.24 & 2.66 \\
\hline 20 & 21.01 & (E) 5-Eicosene & $\mathrm{C}_{20} \mathrm{H}_{40}$ & 280.54 & 6.99 & 25.71 \\
\hline 21 & 23.57 & Citronellol & $\mathrm{C}_{10} \mathrm{H}_{20} \mathrm{O}$ & 156.27 & - & 2.62 \\
\hline 22 & 25.29 & 1-Heneicosanol & $\mathrm{C}_{21} \mathrm{H}_{44} \mathrm{O}$ & 312.58 & 12.00 & - \\
\hline 23 & 25.82 & Phytol & $\mathrm{C}_{20} \mathrm{H}_{40} \mathrm{O}$ & 296.33 & 3.09 & 3.73 \\
\hline 24 & 27.26 & (Z) Hexadecanamide & $\mathrm{C}_{16} \mathrm{H}_{33} \mathrm{NO}$ & 281.48 & - & 2.09 \\
\hline 25 & 27.40 & trans-Fernesol & $\mathrm{C}_{15} \mathrm{H}_{26} \mathrm{O}$ & 222.37 & 3.96 & - \\
\hline 26 & 27.49 & Supraene & $\mathrm{C}_{30} \mathrm{H}_{50}$ & 410.72 & 16.63 & - \\
\hline 27 & 31.16 & Oleamide & $\mathrm{C}_{18} \mathrm{H}_{35} \mathrm{NO}$ & 281.48 & 5.63 & 20.25 \\
\hline 28 & 32.34 & Tritetracontane & $\mathrm{C}_{43} \mathrm{H}_{88}$ & 605.18 & 5.09 & - \\
\hline \multicolumn{3}{|c|}{$\%$ identified } & & & 97.78 & 97.23 \\
\hline \multicolumn{7}{|c|}{ Class of terpenes/terpenoids } \\
\hline \multicolumn{3}{|c|}{ Monoterpenoid } & & & 2.32 & 4.57 \\
\hline \multicolumn{3}{|c|}{ Sesquiterpene } & & & - & 12.34 \\
\hline \multicolumn{3}{|c|}{ Sesquiterpenoid } & & & 3.96 & 13.07 \\
\hline \multicolumn{3}{|c|}{ Diterpene } & & & 6.99 & 25.71 \\
\hline \multicolumn{3}{|c|}{ Diterpenoid } & & & 3.09 & 3.73 \\
\hline \multicolumn{3}{|c|}{ Triterpene } & & & 16.63 & - \\
\hline \multicolumn{3}{|c|}{ Total terpene/terpenoid } & & & 32.90 & 59.42 \\
\hline \multicolumn{3}{|c|}{ Non-terpene derivatives } & & & 64.88 & 37.81 \\
\hline
\end{tabular}


Samples having phenolic moieties exhibit good antioxidant activity [34]. Hence, the moderate antioxidant activity of the essential oil could be due to the presence of phenolic/hydroxyl group constituents such as phytol, citronellol and 5isolongifolol. Phytol is used as a precursor for the manufacture of vitamin E and $\mathrm{K}$, in which Vitamin E is a good antioxidant drug. The compound, 1-Octen-3-ol is a good insect (mosquitoes) repellent that works by blocking the insects' octenol odorant receptors [35]. Therefore, the presence of 1-Octen-3-ol in leaf essential oils of B. pinnatum as the most abundance confirmed that the plant could have insecticidal property [36].

Table $3 \%$ Inhibition and $\mathrm{IC}_{50}$ of leaf and stem B. pinnatum essential oils compared with reference standard

\begin{tabular}{lllllll}
\hline Sample & $\mathbf{1 . 0} \mathbf{~} \mathbf{m g} \mathbf{m L}$ & $\mathbf{5 0 0} \boldsymbol{\mu \mathbf { g } / \mathbf { m L }}$ & $\mathbf{2 5 0} \boldsymbol{\mu \mathbf { g } / \mathbf { m L }}$ & $\mathbf{1 2 5} \boldsymbol{\mu g} / \mathbf{m L}$ & $\mathbf{6 2 . 5} \boldsymbol{\mu g} / \mathbf{m L}$ & $\mathbf{I C}_{\mathbf{5 0}} \boldsymbol{\mu g} / \mathbf{m L}$ \\
\hline BHA & 96.23 & 96.05 & 95.06 & 94.40 & 94.65 & 40.39 \\
Asc. acid & 96.96 & 97.37 & 96.38 & 86.91 & 85.84 & 55.22 \\
Bpleaf & 50.12 & 43.37 & 43.37 & 40.16 & 36.38 & 789 \\
Bpstem & 51.36 & 43.62 & 41.15 & 40.33 & 39.67 & 829 \\
\hline BHA = Butylated hydroxyl anisole, Asc. acid = Ascorbic acid, Bpleaf = Bryophyllum pinnatum leaf, Bpstem = Bryophyllum pinnatum stem
\end{tabular}

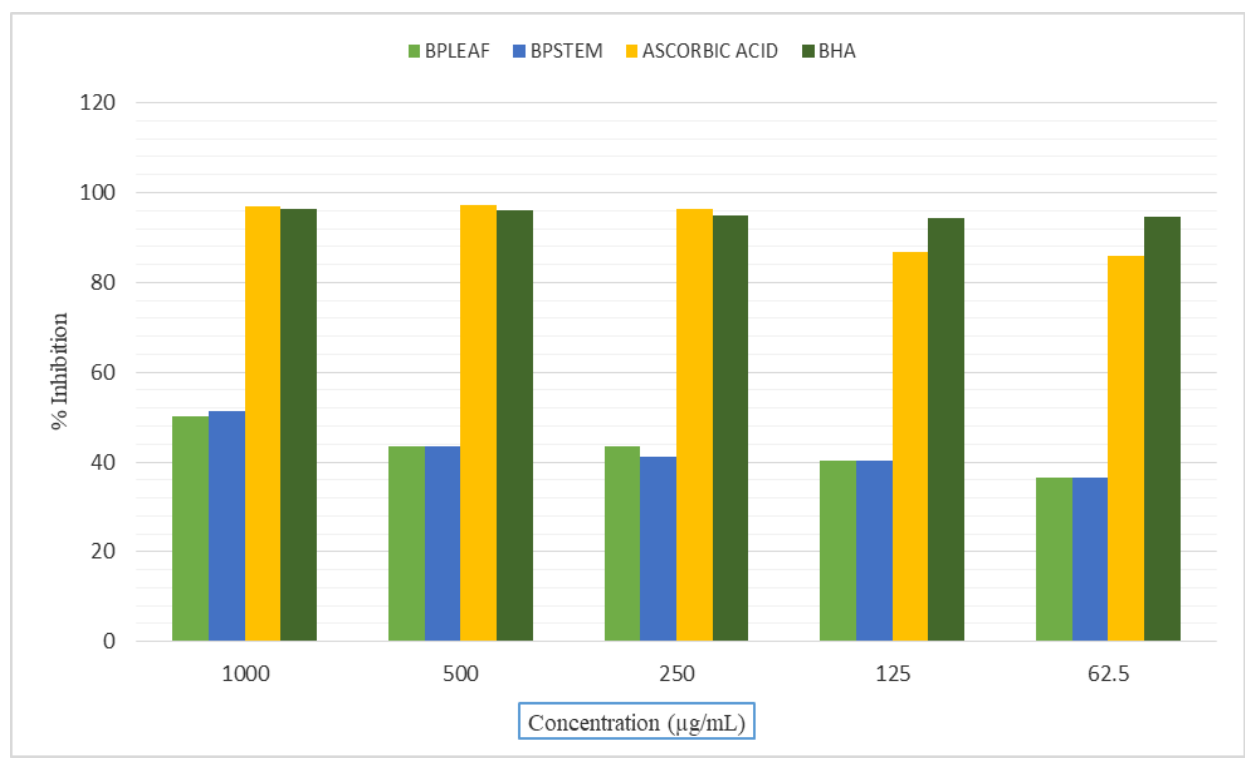

Figure $4 \%$ Inhibition of the leaf and stem essential oils at different concentrations compared with reference standard

\section{Conclusion}

The chemical constituents of leaf and stem essential oil of B. pinnatum are been reported, with moderate antioxidant activity. This could be traced to the presence of vital compounds such as phytol, isolongifolol, $\beta$-gurjunene, $\beta$-bisabolene, citronellol, which are important terpene/terpenoid compounds. The compounds present in these essential oils could account for their usage in ethno-medicine.

\section{Compliance with ethical standards}

\section{Acknowledgments}

The authors are thankful to Department of Chemistry, University of Ibadan, Nigeria and Professor Olusegun Ekundayo for providing the laboratory space and facilities for the extraction and analysis of the essential oils.

\section{Disclosure of conflict of interest}

The authors declare that there is no conflict of interest. 


\section{References}

[1] Al-Snafi AE. (2013). "The Chemical constituents and pharmacological effects of Bryophyllum calycinum. A review," J. Pharma Sci. Res., 4(12), 171-176.

[2] Gill LS. (1992). Ethnomedical uses of plants in Nigeria. Uniben Press.

[3] Kamboj A and Saluja AK. (2009). "Bryophyllum pinnatum (Lam.) Kurz.: Phytochemical and pharmacological profile: A review," Pharmacogn. Rev., 3(6), 364.

[4] Sharma A, Bhot M and Chandra N. (2014). "In vitro antibacterial and antioxidant activity of Bryophyllum pinnatum (Lam.) Kurz," Int. J. Pharm. Pharm. Sci, 6(1), 558-560.

[5] Kirtikar KR, Basu BD and Blatter E. (1975). “Indian Medicinal Plants Periodical Experts," Int. B. Distrib. Delhi, India.

[6] Da Silva SAG, Costa SS, Mendonça SCF, Silva EM, Moraes VLG and Rossi-Bergmann B. (1995). "Therapeutic effect of oral Kalanchoe pinnata leaf extract in murine leishmaniasis," Acta Trop., 60 (3), 201-210.

[7] Salahdeen HM and Yemitan OK. (2006). "Neuropharmacological effects of aqueous leaf extract of Bryophyllum pinnatum in mice," African J. Biomed. Res., 9(2).

[8] Ojewole JAO. (2005). "Antinociceptive, anti-inflammatory and antidiabetic effects of Bryophyllum pinnatum (Crassulaceae) leaf aqueous extract," J. Ethnopharmacol, 99(1), 13-19.

[9] Aransiola EF, Daramola MO, Iwalewa EO, Seluwa AM and Olufowobi 00. (2014). "Anti-diabetic effect of Bryophyllum pinnatum leaves," Group, 120, 3-60.

[10] Gupta R, Lohani M and Arora S. (2010). "Anti-inflammatory activity of the leaf extracts/fractions of Bryophyllum pinnatum Saliv. Syn," Int. J. Pharm. Sci. Rev. Res. 3(1), 16-18.

[11] Okoye EI, Anyaegbunam LC, Obi ZC and Ibemenuga KN. (2013). "Pharmaceutical Constituents of Stem of Bryophyllum Pinnatum," Magnesium 11, 1-38.

[12] Akinsulire OR, Aibin IE, Adenipekun T, Adelowotan T and Odugbemi T. (2007). "In vitro antimicrobial activity of crude extracts from plants Bryophyllum pinnatum and Kalanchoe crenata," African J. Tradit. Complement. Altern. Med., 4 (3), 338-344.

[13] Akinpelu DA. (2000). “Antimicrobial activity of Bryophyllum pinnatum leaves," Fitoterapia, 71 (2), 193-194.

[14] Pal S and Chaudhuri AKN. (1991). "Studies on the anti-ulcer activity of a Bryophyllum pinnatum leaf extract in experimental animals," J. Ethnopharmacol., 33(1), 97-102.

[15] Yamagishi T, Haruna M, Yan XZ, Chang JJ and Lee KH. (1989). "Antitumor agents, 110, Bryophyllin B, a novel potent cytotoxic bufadienolide from Bryophyllum pinnatum," J. Nat. Prod., 52(5), 1071-1079.

[16] Gaind KN and Gupta RL. (1972). "Alkanes, alkanols, triterpenes and sterols of Kalanchoe pinnata," Phytochemistry, 11 (4), 1500-1502.

[17] Mathew PJ and Unnithan CM. (1992). "Search for plants having anti-cancer properties used by the tribals of Wayanad, Malappuram and Palakkad Districts of Kerala, India," Aryavaidyan, 6(1), 61-67.

[18] Steyn PS and Van Heerden FR. (2006). "Bufadienolides of plant and animal origin," 397-413.

[19] Morales AI, Vicente-Sánchez C, Jerkic M, Santiago JM, Sánchez-González PD, Pérez-Barriocanal F and López-Novoa JM. (2006). "Effect of quercetin on metallothionein, nitric oxide synthases and cyclooxygenase-2 expression on experimental chronic cadmium nephrotoxicity in rats," Toxicol. Appl. Pharmacol., 210(2), 128-135.

[20] McKenzie RA, Franke FP and Dunster PJ. (1987). "The toxicity to cattle and bufadienolide content of six Bryophyllum species," Aust. Vet. J., 64(10), 298-301.

[21] Yamagashi T, Yan XZ, Wu RY, Mcphail DR, Mcphail AT and Lee KH. (1988). "Structure And Stereochemistry Of Bryophyllin-A, A Novel Potent Cytotoxic Bufadienolide Orthoacetate From (Bryophyllum) (Pinnatum)," Chem. Pharm. Bull., 36(4), 1615-1617.

[22] Yan X, Lee K and Takashi Y. (1992). "Isolation and identification of cytotoxic components from Bryophyllum Pinnatum," Chinese J. Cancer Res., 4(4), 1-3.

[23] Rastogi RP and Mehrotra BN. (1994). "Isolation and structure determination of a new ellagitannin from the galls of Tamarixaphylla," Compend. Indian Med. Plants, NISCOM, New Delhi, 5, 828. 
[24] Kamaleeswari M and Nalini N. (2006). "Dose response efficacy of caraway (Carumcarvi L.) on tissue lipid peroxidation and antioxidant profile in rat colon carcinogenesis," J. Pharm. Pharmacol., 58(8), 1121-1130.

[25] Deb Roy S, Thakur S, Negi A, Kumari M, Sutar N and Jana GK . (2010). "In vitro antibiotic activity of volatile oils of Carumcarvi and Coriandrum sativum," Int J Chem Anal. Sci, 1, 149-150.

[26] Rodov V, Vinokur Y, Gogia N and Chkhikvishvili I. (2010). "Hydrophilic and lipophilic antioxidant capacities of Georgian spices for meat and their possible health implications," Georg. Med News, 179, 61-66.

[27] Baananou S, Bouftira I, Mahmoud A, Boukef K, Marongiu B and Boughattas NA. (2013). "Antiulcerogenic and antibacterial activities of Apiumgraveolens essential oil and extract,” Nat. Prod. Res., 27(12), 1075-1083.

[28] Aboaba SA, Igumoye H and Flamini G. (2016). "Chemical composition of the leaves and stem bark of Sterculia tragacantha, Anthocleista vogelii and leaves of Bryophyllum pinnatum," 2905.

[29] British Pharmacopoeia. (1980). “109,” HM Station. Off. London2, (109).

[30] Mbachu KA and Moronkola DO. (2017). “Compositions of Thunbergia grandiflora Leaf and Root Essential Oils,” J. Adv. Med. Pharm. Sci., 15(1), 1-8.

[31] Adams RP. (2007). Identification of essential oil components by gas chromatography/mass spectrometry, Allured publishing corporation Carol Stream, IL, 456.

[32] Masada Y. (1976). "Analysis of essential oils by gas chromatography and mass spectrometry,"

[33] Onocha PA, Oloyede GK and Afolabi QO. (2011). “Chemical composition, cytotoxicity and antioxidant activity of essential oils of Acalypha hispida flowers," Inter J Pharm, 7(1), 144-148.

[34] Ogunlana OE, Ogunlana 00 and Farombi EO. (2008). "Morinda lucida: Antioxidant and reducing activities of crude methanolic stem bark extract,” Adv. Nat. Appl. Sci., 2(2), 49-54.

[35] Ditzen M, Pellegrino M and Vosshall LB. (2008). "Insect odorant receptors are molecular targets of the insect repellent DEET," Science 319(5871), 1838-1842.

[36] Supratman U, Fujita T, Akiyama K, Hayashi H, Murakami A, Sakai H, Koshimizu K and Ohigashi H. (2001). "Antitumor Promoting Activity of Bufadienolides from Kalanchoe pinnata and K. daigremontiana butiflora," Biosci. Biotechnol. Biochem., 65(4), 947-949.

\section{How to cite this article}

Mbachu KA, Ibok MG, Adeniyi-Akee MA and Ajala OE. (2019). Chemical compositions and antioxidant activity of leaf and stem essential oils of Bryophyllum pinnatum (lam.) Kurz. GSC Biological and Pharmaceutical Sciences, 9(2), 57-64. 